\title{
Carbenicillin Resistance in Pseudomonas aeruginosa from Clinical Material
}

\author{
J. H. DARRELL,* M.B., M.C.PATH., D.C.H. ; PAMELA M. WATERWORTH, $†$ F.I.M.L.T.
}

British Medical fournal, 1969, 3, 141-143

\begin{abstract}
Cummary : Strains of Pseudomonas aeruginosa resistant to $256 \mu \mathrm{g}$. per ml. or more of carbenicillin (Pyopen) were isolated from 17 patients over a period of three months. The infections were not solely due to crossinfection. Low dosage and attempted eradication of the organism from inaccessible sites, such as the bronchi or skin surfaces, by using systemic treatment are two possible causes. Restraint in treating infections of doubtful importance and the use of local applications to appropriate sites with or without systemic treatment is suggested.
\end{abstract}

\section{Introduction}

Carbenicillin (disodium $\alpha$-carboxybenzyl penicillin; Pyopen) has shown considerable promise in the treatment of infection with Pseudomonas aeruginosa. Not only is it effective in urinary tract infections but some success has been reported in the prevention and even the treatment of the much more diffcult systemic infections caused by this organism (Brumfitt, Percival, and Leigh, 1967 ; Van Rooyen, Ross, Bethune, and MacDonald, 1967 ; Richardson, Spittle, James, and Robinson, 1968 ; Stratford, 1968). We believe that bacteriological cure of a case of pseudomonas endocarditis has been achieved in this hospital with the drug.

In the past three months we have isolated an increasing number of strains of Ps. aeruginosa resistant to carbenicillin. The purpose of this report is to examine the likely reasons for this developing resistance and to suggest possible ways of minimizing it.

\section{Materials and Methods}

The strains reported were isolated over a period of three months in routine clinical laboratory work. Initial sensitivity tests were carried out by Stokes's (1968) method, on 5\% lysed horse blood agar, a 100- $\mu \mathrm{g}$. disc being used. A sensitive strain of Ps. aeruginosa (minimum inhibitory concentration for carbenicillin $32 \mu \mathrm{g} . / \mathrm{ml}$.) was used as the control organism.

Minimum inhibitory concentrations of the drug for strains showing increased resistance in the disc test were determined by use of a plate dilution technique. A light inoculum (1 in 1,000 dilution of an overnight broth culture) was tested on Oxoid Columbia agar by means of a multiple inoculating device. The minimum inhibitory concentrations of 45 sensitive strains isolated during the same period were also determined. The control strain was included with each batch of tests.

Habituation to carbenicillin of two sensitive strains of Ps. aeruginosa (1a and 4a) was investigated in vitro. Serial transfers were performed daily for five days in 5-ml. volumes of tryptone soya broth (Oxoid) containing doubling concentrations of carbenicillin up to $1,024 \mu \mathrm{g} . / \mathrm{ml}$. The inoculum was one standard loopful $(0.004 \mathrm{ml}$.) of the undiluted overnight culture. Minimum inhibitory concentrations for the parent strains and the final cultures were determined as above.

The effect of maintaining organisms by daily subculture for 10 days in a lower concentration of carbenicillin $(25 \mu \mathrm{g} . / \mathrm{ml}$.)

* Senior Lecturer, Department of Bacteriology.

t Senior Demonstrator in Chemotherapy.
Royal Postgraduate Medical School W.12. was tested, the same strains being used. This concentration $\frac{\bar{D}}{\bar{D}}$ was felt to be of the order likely to be attained in the blood as? a result of inadequate treatment. This effect was also tested $\varrho$ with ampicillin $25 \mu \mathrm{g} . / \mathrm{ml}$. under the same conditions.

Resistant strains were transferred 10 times in broth without $\overrightarrow{-}$ antibiotic to determine whether resistance was lost in subculture.After isolation strains were preserved in liquid nitrogen and $\vec{\omega}$ subcultured as little as possible before minimum inhibitory concentrations were determined.

The organisms were typed by the pyocine-typing methodi with Gillies and Govan's (1966) set of indicator strains to seegr whether the observed resistance was due to selection during $\mathcal{E}^{\circ}$ treatment or whether the resistant strain was a different one $\vec{A}$ acquired by cross-infection.

\section{Results}

Table I shows the distribution of minimum inhibitory $\vec{\odot}$ concentrations of carbenicillin for 45 sensitive strains of 6 Ps. aeruginosa. In 34 this was $32-64 \mu \mathrm{g} . / \mathrm{ml}$. A light inoculum was used, as results are known to be considerably influenced by inoculum size (Brumfitt et al., 1967), presumably due to the presence of a minority population of resistant cells. Strains with minimum inhibitory concentrations of $256 \mu \mathrm{g} . / \mathrm{ml} . \stackrel{\mathrm{Q}}{\mathrm{Q}}$ or more have been recorded as resistant.

TABLE I.-Activity of Carbenicillin Against Sensitive Strains of Ps. aeruginosa (45 Strains)

No. of Strains with Minimum Inhibitory Concentration ( $\mu \mathrm{g} . / \mathrm{ml}$.) of:

\begin{tabular}{c|c|c|c|c|c|c|}
\hline 1,024 & 512 & 256 & 128 & 64 & 32 & 16 or $<16$ \\
\hline- & - & - & 6 & 15 & $19^{*}$ & 5 \\
\hline
\end{tabular}

- Including one strain with one or two colonies persisting up to $512 \mu \mathrm{g} . / \mathrm{ml}$.

Data relating to 17 such strains isolated from patients are presented in Table II. The strains were isolated from patients 0 in 10 different wards on more than one occasion in every case. In all but two of the 17 patients an antibiotic of the penicillin 0 group had been given before the resistant organism appeared $\frac{D}{O}$ In five carbenicillin had been used and resistance was first seen during the course of treatment. In another seven the antibiotic $N$ used was ampicillin. In six of these seven patients the first ${ }_{\mathrm{W}}$ strain of Pseudomonas isolated was highly resistant to carbenicillin, as it was in two others, one of whom had received benzylpenicillin with cloxacillin and the other methicillin. Even by the comparatively crude test of pyocine typing the strains were not all the same. Sensitive strains were isolated from six 0 patients before resistance appeared; in four they were of the $\vec{O}$ same pyocine type as the resistant strain isolated subsequently. $\stackrel{\mathbb{D}}{\stackrel{D}{Q}}$ In the other two cases the resistant strain was of a different $\frac{\mathbb{Q}}{2}$ type and was isolated from a different site from that first involved. Among the resistant strains appearing de novo, type 10 was relatively common, but at least four other types 0 were represented.

Of the two sensitive strains passaged in increasing concentra- $\frac{\overline{0}}{7}$ tions of carbenicillin, the minimum inhibitory concentration for the drug increased at least 16-fold in one case and 32-fold in the other. In both cases it came to exceed $1,024 \mu \mathrm{g} . / \mathrm{ml}$. When the same strains were maintained in a constant concentration 
of carbenicillin $(25 \mu \mathrm{g} . / \mathrm{ml}$.) a fourfold rise in minimum inhibitory concentration occurred in one case and a 16-fold rise in the other. The corresponding increases with ampicillin were twofold and fourfold respectively.

TABLE II.-Strains Isolated During Treatment with Carbenicillin

\begin{tabular}{|c|c|c|c|c|}
\hline $\begin{array}{l}\text { Case } \\
\text { No. }\end{array}$ & $\begin{array}{l}\text { Site of } \\
\text { Isolation }\end{array}$ & $\begin{array}{c}\text { Antibiotics } \\
\text { Previously given }\end{array}$ & $\begin{array}{l}\text { M.I.C. } \\
(\mu \mathrm{g} . / \mathrm{ml} .) \\
\text { Carbeni- } \\
\text { cillin }\end{array}$ & $\begin{array}{l}\text { Pyocine } \\
\text { Type }\end{array}$ \\
\hline \multicolumn{5}{|c|}{ Strains Isolated during $\mathrm{Tr}_{r}$} \\
\hline \multirow{2}{*}{$\begin{array}{l}\text { 1. Mitral valve } \\
\text { replacement }\end{array}$} & Wound swab & $\begin{array}{l}\text { Penicillin, strepto- } \\
\text { mycin, kanamycin }\end{array}$ & 64 & $1 / 8$ \\
\hline & Sputum & $\begin{array}{l}\text { Carbenicillin } \\
20 \text { g. daily }\end{array}$ & 1,024 & 10 \\
\hline \multirow[t]{2}{*}{$\begin{array}{l}\text { 2. Double valve } \\
\text { replacement }\end{array}$} & $\begin{array}{c}\text { Tracheostomy ! } \\
\text { wound }\end{array}$ & $\begin{array}{l}\text { Penicillin, } \\
\text { streptomycin } \\
\text { Carbenicillin 10 } \rightarrow\end{array}$ & 64 & 1 \\
\hline & 30020 & 20 g. daily & 1,024 & 1 \\
\hline \multirow[t]{2}{*}{$\begin{array}{l}\text { 3. Intestinal } \\
\text { obstruction }\end{array}$} & $\begin{array}{l}\text { Abdominal } \\
\text { wound }\end{array}$ & Nil & & $1 / 8$ \\
\hline & & & 256 & $1 / 8$ \\
\hline \multirow[t]{2}{*}{$\begin{array}{l}\text { 4. Mitral valve } \\
\text { replacement }\end{array}$} & $\begin{array}{l}\text { Tracheostomy ! } \\
\text { wound }\end{array}$ & $\begin{array}{l}\text { Penicillin, } \\
\text { streptomycin } \\
\text { Carbenicillin }\end{array}$ & 32 & $1 / 8$ \\
\hline & & $4 \mathrm{~g}$ & 256 & $1 / 8$ \\
\hline $\begin{array}{l}\text { 5. Carcinoma of } \\
\text { colon }\end{array}$ & $\begin{array}{l}\text { Urine } \\
\text { Abdominal } \\
\text { wound }\end{array}$ & $\begin{array}{l}\text { Nil } \\
\text { Carbenicillin } 4 \text { g. daily }\end{array}$ & $\begin{array}{r}64 \\
1,024\end{array}$ & $\begin{array}{l}\text { NT } \\
10\end{array}$ \\
\hline \multicolumn{5}{|c|}{ Strains from Patients not Treated with Carbenicillin } \\
\hline $\begin{array}{l}\text { 6. Respiratory } \\
\text { failure }\end{array}$ & Sputum & $\begin{array}{l}\text { Nil } \\
\text { Ampicillin }\end{array}$ & $\begin{array}{r}32 \\
256\end{array}$ & $\begin{array}{l}1 / 2 \\
1 / 2\end{array}$ \\
\hline \multirow{10}{*}{$\begin{array}{l}\text { 7. Carcinoma of } \\
\text { bronchus } \\
\text { 8. Urinary } \\
\text { infection } \\
\text { 9. Indwelling } \\
\text { catheter } \\
\text { 10. Chronic bron- } \\
\text { chitis (\#femur) } \\
\text { 11. Cushing's syn- } \\
\text { drome (pituit- } \\
\text { ary implant) } \\
\text { 12. Multiple } \\
\text { injuries } \\
\text { 13. Mitral valve } \\
\text { replacement } \\
\text { 14. Bronchopleural } \\
\text { fstula } \\
\text { 15. Rheumatoid } \\
\text { arthritis } \\
\text { (PS.B.E.) } \\
\text { 16. Acute renal } \\
\text { failure } \\
\text { 17. Carcinoma of } \\
\text { bladder }\end{array}$} & Sputum & Ampicillin & 256 & 1 \\
\hline & Sputum & Ampicillin & 1,024 & UTa \\
\hline & Urine & Ampicillin & 1,024 & 10 \\
\hline & Sputum & Ampicillin & 1,024 & 10 \\
\hline & Sputum & $\begin{array}{l}\text { Ampicillin, } \\
\text { trimethoprim }\end{array}$ & $>1,024$ & 10 \\
\hline & $\begin{array}{l}\text { Tracheostomy } \\
\text { suckings }\end{array}$ & Ampicillin & 1,024 & 10 \\
\hline & $\begin{array}{l}\text { Tracheostomy } \\
\text { suckings } \\
\text { Wound swab }\end{array}$ & $\begin{array}{l}\text { Penicillin, } \\
\text { cloxacillin } \\
\text { Methicillin }\end{array}$ & $\begin{array}{l}1,024 \\
1,024\end{array}$ & $\begin{array}{l}10 \\
10\end{array}$ \\
\hline & Sacral sore & $\begin{array}{l}\text { Penicillin, } 15 \text { mega } \\
\text { daily }\end{array}$ & 256 & UTb \\
\hline & Urine & Nil & 512 & NT \\
\hline & Urine & $\mathrm{Nil}$ & 512 & 1 \\
\hline
\end{tabular}

NT $=$ Non-typable. UTa and UTb $=$ Two different strains showing inhibition but not corresponding to a known pyocine type.

The results of subculture of 12 resistant strains in medium free of antibiotic are summarized in Table III. In six of the 12 strains there was a fall in resistance. In only one was resistance completely lost. This loss of resistance was also seen

TABLE III.-Fold Decrease in Resistance to Carbenicillin of 12 Strains of Ps. aeruginosa After 10 Transfers in Antibiotic-free Broth

\begin{tabular}{l|l|r|r|r|r|r|r}
\hline Pold decrease & 0 & -2 & -4 & -8 & -16 & -32 & -64 \\
No. of strains & 6 & 2 & 2 & 1 & 0 & 0 & 1 \\
\hline
\end{tabular}

in vivo but not in vitro, with the strain from Case 4 . The organism was not eradicated by treatment; it became resistant, but reverted to full sensitivity after treatment was stopped. The pyocine type remained the same throughout. In five strains reduction in resistance was moderate (fourfold to 16 -fold), the minimum inhibitory concentration remaining at $256 \mu \mathrm{g} . / \mathrm{ml}$. or above in three of these. In the remaining six strains there was no change.

\section{Discussion}

The greatest potential use of carbenicillin lies in its activity against Ps. aeruginosa. The level of this activity is low compared with that against other Gram-negative rods, the minimum inhibitory concentration for Ps. aeruginosa being 32-64 $\mu \mathrm{g} . / \mathrm{ml}$. as against 2-4 $\mu \mathrm{g} . / \mathrm{ml}$. for Escherichia coli and non-penicillinase-producing strains of Proteus mirabilis. The toxicity of other drugs active against Ps. aeruginosa, and in the case of the polymyxins their inexplicably poor effect in vivo, makes even this degree of activity (necessitating high doses often requiring intravenous administration) nevertheless useful. That Ps. aeruginosa is already showing high levels of resistance to $\stackrel{\mathbb{2}}{2}$ carbenicillin is disturbing.

Increased resistance has been seen during treatment with $\overrightarrow{\vec{D}}$ carbenicillin, but otherwise resistant strains have appeared most commonly after treatment with other antibiotics, usually peni- $\frac{C}{\sigma}$ cillins. When it occurred during carbenicillin treatment two $\overline{\bar{c}}$ mechanisms seemed to be operating. Inadequate dosage was $\vec{\nabla}$ not the sole cause, though this is a potent method of selection of resistant mutants, and the necessity for very large doses of क this antibiotic for pseudomonal infections other than of the $\vec{o}$ urinary tract does not appear to be widely enough known. In $\overrightarrow{\vec{H}}$ Cases 2, 3, and 4 the resistant organism was of the same pyocine $\vec{\omega}$ type as the sensitive strain previously isolated, and resistant mutants, existing as a minority population, have probably been selected by low concentrations of the drug. In Case 4 the dose was clearly too low. In Case 3 it was felt to be adequate $\mathscr{J}$ because of the small size of the patient, but may not have been. After doubling the dose to $20 \mathrm{~g}$. Case 2 had a blood carbenicillin level of $1,125 \mu \mathrm{g} . / \mathrm{ml}$. This would be considered more than adequate for the treatment of systemic infections and to prevent $O$ the selection during treatment of resistant mutants, some of which (Cases 3 and 4) show resistance of only a moderate order. Nevertheless, it raises another point-namely, how far are blood levels relevant to surface infection or contamination of skin lesions (for example, surgical wounds or pressure sores), particularly with highly resistant strains with minimum inhibitory concentrations in excess of $1,000 \mu \mathrm{g} . / \mathrm{ml}$.

In the other two patients (Cases 1 and 5) the resistant organism was of a different pyocine type from that originally isolated and was present at a different site. In Case 1 it appeared in the sputum, another site where it may be difficult to achieve high levels of antibiotics in the absence of acute inflammation. In Case 5 successful treatment of a urinary infection with the lower dose regimen was followed by increased resistance of a different strain present in the patient's operation wound. Stratford (1968) reported an exactly similar episode.

The reason for the appearance of carbenicillin-resistant strains of Pseudomonas following treatment with other penicillins is not clear. Although we record 10 such cases, the majority following ampicillin, it is not an invariable occurrence. At least as many patients have acquired sensitive strains under the same circumstances. Preliminary experiments indicate that ampicillin is not an efficient agent for increasing resistance to carbenicillin in vitro. We are investigating penicillinase production of strains before and after passage in both carbenicillin and ampicillin. Garrod (1951), however, reported the apparent stimulating effect of penicillin on Ps. aeruginosa, and our resistant strains may have followed a relatively non-specific selective action. Half the strains were of one pyocine type (type 10), and the two strains acquired during carbenicillin treatment were also of this type. Though these infections appeared over a short period in widely separated wards, crossinfection may have played a part but was not the sole explanation.

Ps. aeruginosa may infest a site without causing progressive infection. The possibility of eventual blood-stream invasion is worrying, and if not a hazard to the patient the organism constitutes a source of infection for others. The decision to treat or not to treat is a difficult one, and possibly it should more often be the latter. If systemic carbenicillin treatment is chosen nothing less than full dosage (20-30 g. daily) should be used except for urinary infections. Stratford (1968) recommends that if there is any doubt that the infection is not completely localized to the urinary tract the higher dosage schedule should be used here also. Even full doses with or 
without the use of probenecid may, however, fail to produce adequate levels at skin surfaces and in the bronchial tree. We have also seen an anuric patient in whom Pseudomonas persisted in the bladder despite a blood carbenicillin level of $750 \mu \mathrm{g} . / \mathrm{ml}$.

Perhaps the most fruitful approach to this problem would be the application of suitable topical agents, but not carbenicillin, to any potentially infected accessible sites. Such treatment reduces dissemination from colonized sites and, used in conjunction with systemic treatment, might reduce the emergence and spread of carbenicillin-resistant strains. Though we have been unable to show convincing synergy between carbenicillin and gentamicin, their combined use might be justified to prevent the selection of resistant mutants.
We wish to thank our clinical colleagues under whom the patients referred to were admitted, Miss Audrey Fryer-Kelsey for her technical assistance, and Mrs. Beryl Devenyi for pyocine-typing the strains.

\section{REFERENCES}

Brumfitt, W., Percival, A., and Leigh, D. A. (1967), Lancet, 1, 1289. Garrod, L. P. (1951). British Medical fournal, 1, 205

Gillies, R. R., and Govan, J. R. W. (1966). Fournal of Pathology and Bacteriology, 91, 339 .

Richardson, A. E., Spittle, C. R., James, K. W., and Robinson, O. P. WO (1968). Postgraduate Medical fournal, 44, 844

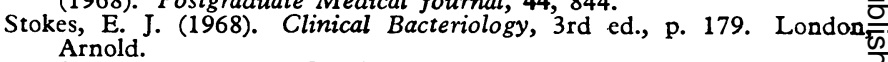

Stratford, B. C. (1968). Medical fournal of Australia, 2, 890.

Van Rooyen, C. E., Ross, J. F., Bethune, G. W., and MacDonald, A. C (1967). Canadian Medical Association fournal, 97, 1227.

\title{
Effects of $\beta$-Adrenergic Receptor Blockade on Airway Conductance and Lung Volume in Normal and Asthmatic Subjects
}

\author{
P. S. RICHARDSON,* B.M., B.SC.; G. M. STERLING, † M.B., M.R.C.P.
}

Summary : Ten normal and five asthmatic subjects were given intravenous injections of $10 \mathrm{ml}$. of $0.9 \%$ saline with and without $10 \mathrm{mg}$. of propranolol, and specific airway conductance was followed in a whole-body plethysmograph. Saline alone had no significant effect on conductance in either group of subjects. Propranolol had no significant effect on conductance in normal subjects, but caused a mean fall of $\mathbf{3 4 . 9 \%}$ in the asthmatics.

\section{Introduction}

Blockade of $\beta$-adrenergic receptors by propranolol in asthmatic subjects often causes wheezing and a pronounced decrease in vital capacity (V.C.) and forced expiratory volume in one second (F.E.V.. ) (McNeill, 1964 ; Langer, 1967). The effect of $\beta$-blockade on the airways of normal subjects is less certain : Zaid and Beall (1966) found no change in F.E.V.1 after propranolol, and Marcelle et al. (1968) obtained the same result, using the interrupter method to measure airway resistance. On the other hand, McNeill and Ingram (1966) and MacDonald et al. (1967), who used the more sensitive method of whole-body plethysmography, reported a significant increase in airway resistance in normal as well as asthmatic subjects after intravenous propranolol. This question is examined further in the present paper, in which the effects of propranolol on airway calibre of normal and asthmatic subjects are compared.

\section{Subjects and Methods}

Ten normal adults with no history or signs of chest disease and five asthmatic subjects were studied. The latter were all clinical students or junior medical staff who agreed to take part in the trial after being informed of the possible effects of propranolol on airway resistance in asthmatics. At the time of testing they were all symptom-free, had had no major attack of asthma for at least three months, and had a resting F.E.V..$_{1}$ of more than 2 litres.
Airway resistance (Raw) and thoracic gas volume (Vtg) were measured by means of a constant-volume whole-body plethysmograph (DuBois et al., 1956a, 1956b). During the measurements the subjects performed shallow panting at? about two breaths per second through a Fleisch pneumotacho- $\frac{D}{D}$ graph head, and flow and pressure signals were displayed as vector loops, the slopes of which were measured by visualo alignment with a rotating Perspex disc mounted in front of the oscilloscope screen (Sterling, 1968). Each value of Raw was derived from the average of five successive short periods of panting after the first two had been discarded. Vtg was measured by the method of DuBois et al. (1956a) during? attempted gentle respiratory efforts made against a shutter occluding the airway at the mouth. After subtraction of $0.45 \mathrm{~cm} . \mathrm{H}_{2} \mathrm{O} / 1 . / \mathrm{sec}$. for the resistance of the pneumotachograph head and mouth-piece, Raw was converted to its reciprocal, airway conductance (Gaw), and results are ex-은 pressed as changes in the ratio:

$$
\frac{\mathrm{Gaw}}{\mathrm{Vtg}}=\text { Specific airway conductance (SGaw). }
$$

Experiments on each subject were done on two days, on $\widetilde{N}$ one of which $10 \mathrm{mg}$. of propranolol in $10 \mathrm{ml}$. of $0.9 \%$ saline $\omega$ was injected intravenously, and on the other $10 \mathrm{ml}$. of saline alone. The order of the injections was varied, 7 out of 100 normal subjects and three out of five asthmatics receiving $\Phi$ propranolol first. Raw and Vtg were measured at 15-minute?+intervals before and after the injections in order to assess $\frac{0}{0}$ spontaneous variability and not to miss any delayed responses. The tests were done "blind" in that the operator reading $\frac{\rho}{\mathbb{D}}$ the vector slopes was not informed of the contents or order $\varrho$ of the injections until the end of the study. The subjects were unable to distinguish between saline and propranolol, and 8 were unaware of the order of injections.

* House-physician, Respiratory Department, St. George's Hospital, London S.W.1.

† Research Registrar, Respiratory Department, St. George's Hospital, London S.W.1. Present address: University Laboratory of Physiology, Oxford.

Reprint requests to: Dr. P. S. Richardson, St. George's Hospital, London 